\title{
EDGE-WISE TEKNİK VE CHİN-CAP TEDAVİSİNE BAĞLI STRES HORMONLARINDAKİ DEĞİŞİMİN PERYODİK ARALIKLARLA İNCELENMESİ ${ }^{*}$ PERIODICAL EXAMINATION OF THE CHANGES IN THE STRES HORMONES
DEPENDENT UPON EDGE-WISE TECHNIQUE AND CHIN-CAP TREATMENT ${ }^{*}$
} 1

öz

Bu çalışma, pubertal büyüme atılımı başlamamış bireylerde chin-cap ve edge-wise tedavi tekniklerinin, stres hormonlarına olan etkilerini incelemek amacıyla yapılmıştır.

Edge-wise mekaniklerinin uygulandığı tedavi grubu, 4 adet premolar dişin çekimi dışında başka bir yöntemle yer intiyacının karşılanamayacağı, şiddetli çapraşıklık gösteren 19 bireyden oluşmaktadır.

Chin-cap ile tedavi edilenler ise, alt çenenin kapanış anında üst çeneye göre daha önde konumlanmasına bağlı, iskeletsel Sınıf III ilişki gösteren 20 bireyden oluşan yalancı prognatili vakalardır.

Araştırma kapsamına alınan bireylerden, tedaviye başlamadan 1 gün önce, tedaviye başladıktan 1 hafta, 2 hafta, 1 ay, 2 ay, 4 ay ve 6 ay sonra olmak üzere toplam 7 kez kan alınmıştır. Araştırmamızın materyalini, alınan kan örneklerinde kortizol, ACTH, büyüme hormonu ve prolaktin için yapılan, biyokimyasal ölçümler oluşturmaktadır.

Çalışmamızda, uygulanan ortodontik ve ortopedik kuvvetin vücutta bir strese yol açıp açmayacağı araştırımak istendiğinden, bu strese karışabilecek psikolojik stresleri ayırt etmek amacıyla, bireyler kan alınan her seansta psikolojik testlere tabi tutulmuştur. İstatistiksel analizler sonucunda; gerek ortodontik gerekse ortopedik tedavi gören bireylerin stres hormonlarında istatistiksel olarak anlamlı değişiklikler gözlenmemiştir. Her iki grupta da kortizol, ACTH, büyüme hormonu ve prolaktinin 1., 2., 3., 4., 5., 6., ve 7. ölçümleri arasında istatistiksel olarak önemli farklar bulunamamışıır.

Anahtar Kelimeler: Stres hormonu, Ortodontik tedavi, kronik stres

\section{ABSTRACT}

This study investigated the effects of the chin-cap and edge-wise treatment techniques on the stress hormones in individuals whose pubertal growth has not started.

The treatment group in which the edge-wise mechanics are applied basically consists of 19 individuals representing severe crowding in which the need for space can only be met with the extraction of 4 premolar teeth.

The patients treated with the chin-cap have the cases of pseudo-prognathie consisting of 20 individuals with a skeletal Class III relationship due to the jaw as it positions ahead of the maxilla at the time of occlusion.

As for the patients in this research, the blood drawing process was as follows: a day before, a week after, two weeks after, a month after, two months after, four months after and six months after the whole treatment, making a total of 7 . The material of this study consists of biochemical measurements for cortisol, ACTH, growth hormone and the prolactin in the blood samples. Individuals were subjected to the psychological tests in each session of blood taking to differentiate the psychological stresses interfering with this stress as this study investigated whether the orthodontic and orthopedic forces cause stress in the body. Statistically significant changes were not observed in the stress hormones of individuals undergoing the orthodontic or orthopedic treatment as a result of the statistical analysis. In both groups, there were no statistically significant differences between the 1st,2nd,3rd,4th,5th,6th and 7th measurements of the cortisol, ACTH, growth hormone and the prolactin.

Keywords: stress hormone, orthodontic treatment, chronic stress

*Atatürk Üniversitesi Diş Hekimliği Fakültesi Ortodonti A.D. Ankara.

${ }^{\text {F}}$ Tezimden üretilmiş bir yayındır.

Kaynakça Bilgisi: Bayındır Durna N, Erdem A. Edge-Wıse Teknik Ve Chin-Cap Tedavisine Bağı Stres Hormonlarındaki Değişimin Peryodik Aralıklarla İncelenmesi. Atatürk Üniv Diş Hek Fak Derg 2020; 30: 464-75.

Citation Information: Bayindir Durna N, Erdem A. Periodical Examination of the Changes in the Stres Hormones Dependent Upon Edge-Wise Technique And ChinCap Treatment. J Dent Fac Atatürk Uni 2020; 30: 464-75. 


\section{GİRİŞ}

Stres terimi; günümüzde biyoloji, sağlık bilimleri, sosyal bilimler gibi değişik alanlarda devamlı ve yaygın bir şekilde kullanılmakla birlikte, önceden beri var olan bir kavramdır.

1914'de Canon, ${ }^{1}$ bu terimi psikoendokrin çalışmalarında, psikolojik ve fizyolojik anlamda kullanmıştır. Canon $^{2} 1935$ yılında yayınladığı makalesinde ise, hem fiziksel hem de psikolojik stimülusun, strese sebep olabildiğini belirtmiştir. Bununla birlikte biyolojik anlamda stres terimi ilk kez 1946 yılında ve Selye ${ }^{3}$ tarafından kullanılmaya başlanmıştır. Selye ${ }^{4}$ daha sonraki çalışmalarında fizyolojik stresin 3 komponentini tanımlamıştır ki bunlar; stresi başlatan eksojen veya endojen (dış çevre veya vücudun kendisinden kaynaklanan) stimulus yani stresör, stresörlerin oluşturduğu fiziksel veya kimyasal etkiler ve vücudun strese verdiği cevaptır.

Son 25 yıldır yapılan araştırmalar, hipofiz bezi ve adrenal korteksin emosyonel, psikolojik ve fiziksel streslere önemli derecede hassas olduğunu göstermiştir. Bu streslere karşı cevap, kortikotropin releasing hormonun hipotalamustan salınması ile birlikte, endokrin sistem tarafından başlatılır. Otonom ve sempatik sinir sistemi ile immün sistem de bu cevaba eşlik eder. ${ }^{5}$

Hipotalamik stimülan faktörlere cevapta, stresin niteliği, şiddeti ve süresi gibi faktörler önemlidir. ${ }^{6}$ Örneğin; anterior hipofiz hormonlarından $\mathrm{ACTH}$, az bir uyaranla kolaylıkla salınabilirken, prolaktin salınması için daha şiddetli bir stres uyaranı gereklidir. ${ }^{7}$ Prolaktinin strese karşı cevabı, uygulanan stresin şiddetine paralel olarak artar. Yani prolaktin, stresin şiddetine duyarlıdır. Bunun aksine büyüme hormonu, luteinizing hormon, tirotropin gibi diğer anterior hipofiz hormonlarının seviyesi, stresin şiddetinden bağımsız olarak değişir. $^{8}$

Ayrıca Selye'nin ${ }^{3}$ çok erken dönemlerde yaptığı çalışmalardan, aynı stresin sürekli uygulanmasıyla beraber, organizmanın verdiği cevapta zamanla bir azalmanın meydana geldiğini biliyoruz. Selye bu durumu Adaptasyon olarak tanımlamıştır.

Uzun süren psikolojik stresin, fiziksel bir hastaıı̆ın oluşmasına katkıda bulunduğu hatta sebep olduğuna dair bilgi, çok eskilere dayanır. ${ }^{5}$ Örneğin, meme kanserinin melankolik kadınlarda, neşeli kadınlardan daha sık görüldüğü ifade edilmiştir. ${ }^{9}$ Yine 1960 'lı yıllarda araştırıcılar, ${ }^{5}$ çalışmalarında; savaş filmi seyrederken bireylerin plazma kortizol seviyesinin arttığını, Walt Disney filmi seyreden kişilerde ise plazma kortizolünün azaldığını bulmuşlardır. Görüldüğü gibi bireylerin psikoloji ve fizyolojilerini birbirinden ayırmak ya da ayrı ayrı düşünmek mümkün değildir. Her iki kavram da birbiriyle etkileşir ve ortak etkiler meydana getirir.

Psikolojik faktörler ile ortodontik maloklüzyonların da ilişkili olduğu, yapılan tedavilerin, hastanın özgüvenini arttırdığı bilinmektedir. Gelişimi çocukluktan erişkinliğe kadar devam eden insan psikolojisi üzerine, fasiyal estetik kavramının etkisinin büyük olduğu düşünülmektedir. ${ }^{10}$

Yapılan bir çalışmada ${ }^{11}$ yüz estetiğinin, kişinin kendisi ile barışık olması ve sosyal olarak ilişkilerini pozitif yönde etkilemesi bakımından önemli olduğu bildirilmiştir.

Literatür incelemesinde, ortodontik ve ortopedik tedaviler sonucunda meydana gelen değişiklikleri inceleyen çok sayıda çalışmaya rastlanmış, ${ }^{12,13}$ ancak bu tedavilerin biyokimyasal etkileri ile ilgili olarak yeterli bir bilgiye ulaşılamamıştır.

Çalışmamızın amacı; maloklüzyon, malpozisyon gibi dişsel düzensizliklerin edge-wise tekniği ile negatif ANB açıSı, fonksiyonel Sınıf III anomalisi gibi iskeletsel problemlerin ise chin-cap ile tedavi edildiği, pubertal büyüme atılımı başlamamış bireylerde, stres hormonlarında meydana gelen değişikliği periyodik aralıklarla incelemektir. Aynı bireylerde, stres hormonlarında meydana gelen değişikliğin tedaviye bağlı olarak mı yoksa hastanın korku ve kaygılarından mı kaynaklandığını tespit etmektir.

\section{MATERYAL VE METOT}

$\mathrm{Bu}$ çalışmanın materyali, Atatürk Üniversitesi Diş Hekimliği Fakültesi Ortodonti Anabilim Dalına, tedavi amacıyla müracaat eden, yaşları 9-13 arasında değişen sağlıklı 12 kız, 27 erkek, toplam 39 bireyden oluşmuştur. Öncelikle hastalara ve ebeveynlerine çalışma hakkında bilgi verilmiş ve onam formu imzalatılmıştır.

Puberta ile birlikte cinsiyete bağlı olarak meydana gelebilecek hormonal değişiklikleri ekarte etmek için, bireylerin büyüme atılımlarının başlamamış olmasına dikkat edilmiştir. ${ }^{14}$

Stres hormonlarından Kortizol, ACTH, Büyüme hormonu ve Prolaktinde meydana gelen değişim, ortodontik ve ortopedik olmak üzere 2 farklı kuvvetin uygulandığı, 2 ayrı tedavi grubu üzerinde incelendi.

Ortodontik kuvvet, alt ve üst diş dizilerinde, ark boyut sapmalarının $5 \mathrm{~mm}$ 'den fazla olduğu şiddetli çapraşıklığa sahip bireylere, edge-wise mekanikleri ile uygulandı.

Edge-wise tekniği ile 15 erkek, 4 kız toplam 19 
birey üzerinde çalışıldı. Tüm bireylerde, alt ve üst çenedeki birinci veya ikinci premolarların çekimlerini öngören, tedavi planı yapıldı. Hastaların çoğunda, üst çenede Nance, alt çenede lingual ark ile ankraj kontrolü sağlandı. Araştırmaya dâhil edilen bireylerin, oral hijyenleri uygun hâle getirilmeden, tedavilerine başlanmadı.

Diş çekimi cerrahi bir işlem olduğundan, oluşturabileceği stres ile diş hareketleriyle meydana geleceğini beklediğimiz stresi ayırt etmek için hastaların tedavilerine, çekimlerin tamamlanmasından yaklaşık 10 gün sonra başlandı. Ortopedik kuvvet, chin-cap aracıIığı ile yalancı prognati vakalarında uygulandı. Bu tedavi grubunun oluşturulmasında belirlenen kriterler şunlardır:

- Klinik Olarak: Kesici dişler bölgesinde ön çapraz veya baş başa kapanış, azılar bölgesinde ise Angle sınıf III ilişkisinin bulunması, çeneler sentrik ilişkide iken mandibulanın manuel olarak geriye alınabilmesi,

- Sefalometrik olarak; ANB açısının en az 1 derecenin altında olması, ${ }^{15}$ çeşitli sebeplerden dolayı (prematür kontaklar, tonsilla hipertrofısi, taklitçilik, vb.) alt çenenin kapanış anında öne doğru kayarak ileride konumlanmasına bağlı iskeletsel sınıf III ilişkisinin bulunması ve normal sınırlar içerisinde olan korpus uzunluğudur. Sefalometrik olarak istenen şartlara uyabilecek hastaların radyografik tanıları, lateral sefalometrik filmler aracılığı ile yapıldı.

Alt çenenin gelişim yönünün değiştirilmesi hedeflenerek, ağız dışı aygıt ile tedavi edilen bu gruptaki bireyler, mikst dentisyon dönemindeydi. Araştırma kapsamına dâhil edilen 8 kız, 12 erkek toplam 20 vakanın hepsine oklüzyon yükseltici ilave edildi.

Chin-cap ile tek taraflı ortalama 500-600 gr. olmak üzere toplam 1000-1200 gr. kuvvet uygulandı. Hastaların bu aygıtı bir günlük taşıma sürelerinin en az 16-18 saat olmasına dikkat edildi.

Çeneliğin, çene ucu yumuşak dokulara ve alt dudağa uyguladığı kuvvetin etkisiyle, alt keser dişlerin linguale tipping yapmasını engellemek amacıyla, alt çeneye pasif bir lingual ark yapıldı.

Hem edge-wise hem de chin-cap grubundaki hastalar, dört haftada bir kontrol için çağrıldı ve rutin muayeneleri yapıldı. Her iki gruba da dâhil edilen bireylerin;

- Herhangi bir mental, hormonal ve sistemik problemlerinin bulunmamasına,

- Daha önce ortopedik veya ortodontik tedavi görmemiş olmalarına,
- Pubertal büyüme atılımlarının başlamamış olmasına dikkat edildi.

Bireylerden tedaviye başlamadan önce ve takip edilen 6 aylık sürenin sonunda üzere toplam iki adet el-bilek filmi alındı.

Bireylerin pubertal büyüme atılımı düzeyi Greulich -Pyle ${ }^{16}$ atlasına göre değerlendirildi. Büyüme atılımlarının başlamış olduğu gözlenen vakaların biyokimyasal kayıtları, çalışmaya dâhil edilmedi. Son altı ay içerisinde, akut romatizmal kardit gibi, tedavisinde kortizol türevi ilaçların kullanıldığı, herhangi bir hastalık geçiren bireyler de çalışma dışı bırakıldı.

Stres hormonlarındaki değişiklik, kan tablosuna bakılarak değerlendirildi. Hastalardan tedaviye başlamadan 1 gün önce, tedaviye başladıktan 1 hafta, 2 hafta, 1 ay, 2 ay, 4 ay ve 6 ay sonra olmak üzere toplam 7 defa kan alındı.

Her bir seansta 10 ml'lik plastik enjektörler kullanılarak yaklaşık $8 \mathrm{ml}$ kan alındı. Alınan kanın bir kısmı, antikoagülansız vakumlu bir tüpe aktarıldı. Yarım saat içerisinde $4500 \times$ g'de $^{\prime} \mathrm{dk}$. santrifüj edilerek serumları ayrıldı. Bu serum örneklerinde prolaktin, büyüme hormonu ve kortizol düzeyleri çalışıldı. Geriye kalan kan ise, içerisinde antikoagülan olarak EDTA (Etilen Diamid Tetra Aseticasit) bulunan buzlu bir tüpe aktarılarak, hemen soğutmalı bir santrifüj aletinde $2000 \times$ g'de $10 \mathrm{dk}$. santrifüj edildi ve plazması ayrıldı. Elde edilen plazma örneğinde ise ACTH düzeyleri çalışıldı. Hemolizli örnekler çalışma dışı bırakıldı.

Uygulamakta olduğumuz tedavi yöntemlerinin, incelediğimiz hormonlar üzerindeki etkilerini belirlemek amacıyla, hastalardan kan alındığı her seansta kendileri için düzenlenmiş olan psikolojik anketi doldurmaları istendi.

Kaygı düzeylerinde meydana gelen değişimin değerlendirilmesinde "durumluluk ve sürekli kaygı envanteri" (STAI) kullanılmıştır. ${ }^{17}$ STAI:

- Çocuk hastanın korkularının saptanmasında kullanılan metotlardan, davranış derecelendirme skalalarının bir modifikasyonudur.

- Bireyin kendi kendine yanıtlayabileceği uygulanması kolay bir envanterdir. Okuduğunu anlayıp cevap verebilecek kadar bilinci yerinde olan hastalara uygulanır.

- Durumluluk ve sürekli kaygı düzeylerini ölçer.

- Zaman sınırlaması yoktur.

- Envanterin, her biri 20 maddelik iki ayrı ölçeği vardır.

i. Durumluluk kaygı ölçeği: Bireyin belirli bir anda ve belirli koşullarda kendini nasıl hissettiğini belirler. 
ii. Sürekli kaygı ölçeği: Bireyin içinde bulunduğu durum ve koşullardan bağımsız olarak, kendini nasıl hissettiğini belirler.

Her iki ölçekte de yer alan tüm ifadeler 1-3 puan arasında skorlandırılmıştır. Olumlu duyguları dile getiren ifadeler 1 , biraz ve bazen seçenekleri 2 , olumsuz duyguları dile getiren ifadeler de 3 puan olarak değerlendirilir. Her bir ölçekten elde edilen toplam puan değeri 20-60 arasında değişir. Büyük puan yüksek kaygı seviyesini, küçük puan ise düşük kaygı seviyesini belirtir.

\section{İstatistiksel Değerlendirme}

I. Kortizol, ACTH, büyüme hormonu ve prolaktine ait verilerde, zamana bağlı olarak oluşan değişimleri inceleyebilmek amacıyla Tekrarlı Ölçüm Varyans Analizi (Repeated Measurements of Variance) tekniği uygulanmıştır.

II. Gruplar arasında psikolojik açıdan farklılık olup olmadığını belirlemek için Student's $t$ testi uygulanmıştır. İstatistiksel olarak gruplar arası önemli bir farklııı bulunmadığından, istatistiksel analiz; edge wise ve chin-cap grupları birleştirilerek yapılmıştır. Birleşik grup üzerinde, 6 ay boyunca meydana gelen psikolojik değişiklikleri incelemek için tedavi öncesi belirlenmiş skorlar ile diğer zamanlarda kaydedilmiş skorlar arasında ayrı ayrı Eşleştirilmiş $t$ testi uygulanmiştır.

III. Kullanılan istatistik yöntemi, SPSS (Statistical Package for Social Sciences) for Windows yazılımı (V.10.0.) programında yapılmıştır.

\section{BULGULAR}

Tedavi gruplarında cinsiyet farklılığı olup olmadığı, ön analizde cinsiyet farklılığı grup karşılaştırması testi ile araştırılmış ve incelenen parametrelerde önemli bir cinsiyet farklıı̆̆ bulunamamıştır. Bu nedenle tüm istatistiksel değerlendirmeler, kız ve erkek gruplar birleştirilerek yapılmıştır. Bununla birlikte her bir analizde, bireylerden alınan kan örnekleri üzerinde çalışılırken taşıma, analiz, ortam sıcaklığı vb. neticesinde oluşan ve normal dağılım için problem oluşturacak aykırı değerler istatistiksel hesaplamalara dâhil edilmemiştir. İstatistiksel hesaplamalara dâhil edilen birey sayıları tablolarda belirtilmiştir.

İncelenen parametrelere ait, periyodik aralıklarla tekrarlanmış ölçümlerin varyans analizi sonuçları göz önünde bulundurulduğunda, tüm parametrelerde edge-wise ve chin-cap grupları arasında istatistiksel olarak önemli farklılıklar gözlenmemiştir.

Kortizol, büyüme hormonu, ACTH ve prolak- tinin, her iki grupta da 1., 2., 3., 4., 5., 6 ve 7. ölçüm zamanları için ortalama ve standart sapma değerleri (Deskriptif istatistik) Tablo 1- 4'te verilmiştir. Elde edilen sonuçlara göre, tedavi gruplarındaki hormonların zamana bağlı değişim diyagramları Şekil 1-4'te gösterilmiştir.

Edge-wise mekanikleri ile tedavi edilen bireylerde, tedavi öncesi kortizol, ACTH, prolaktin değerleri 6 ay sonunda önemli olmayan düzeyde azalırken, büyüme hormonunda istatistiksel olarak anlamlı olmayan artış gözlenmiştir.

Tablo 1. Edge-wise ve chin-cap gruplarında kortizolün zamana bağlı değişikliklerini gösteren ortalama ve Standard sapma değerleri.

\begin{tabular}{|c|c|c|c|c|}
\hline Zaman & Grup & $\mathrm{n}$ & Ortalama & Standard sapma \\
\hline \multirow{2}{*}{$\begin{array}{c}\text { Tedavi } \\
\text { oncesi }\end{array}$} & Edge-wise & 16 & 15,45 & 6,23 \\
\cline { 2 - 5 } 1 hafta & Chin-cap & 17 & 14,31 & 6,73 \\
\cline { 2 - 5 } & Edge-wise & 16 & 15,75 & 7,65 \\
\cline { 2 - 5 } 2 hafta & Chin-cap & 17 & 15,11 & 5,21 \\
\cline { 2 - 5 } & Edge-wise & 16 & 13,60 & 3,83 \\
\hline \multirow{2}{*}{1 ay } & Chin-cap & 17 & 16,24 & 6,56 \\
\cline { 2 - 5 } & Edge-wise & 16 & 13,20 & 5,86 \\
\hline \multirow{2}{*}{2 ay } & Chin-cap & 17 & 14,83 & 5,44 \\
\cline { 2 - 5 } & Edge-wise & 16 & 14,22 & 6,52 \\
\hline \multirow{2}{*}{4 ay } & Chin-cap & 17 & 15,56 & 5,56 \\
\cline { 2 - 5 } & Edge-wise & 16 & 13,78 & 6,42 \\
\hline \multirow{2}{*}{6 ay } & Chin-cap & 17 & 14,21 & 5,67 \\
\cline { 2 - 5 } & Edge-wise & 16 & 13,77 & 8,42 \\
\hline & & 17 & 15,70 & 6,30 \\
\hline
\end{tabular}

Tablo 2. Edge-wise ve chin-cap gruplarında büyüme hormonunun zamana bağı değişikliklerini gösteren ortalama ve Standard sapma değerleri.

\begin{tabular}{|l|c|c|c|c|}
\hline Zaman & Grup & $\mathrm{n}$ & Ortalama & Standart sapma \\
\hline \multirow{2}{*}{$\begin{array}{l}\text { Tedavi } \\
\text { önesi }\end{array}$} & Edge-wise & 15 & 1,38 & 3,73 \\
\cline { 2 - 5 } 1 hafta & Chin-cap & 17 & 2,03 & 6,12 \\
\hline \multirow{2}{*}{2 hafta } & Edge-wise & 15 & 1,53 & 2,73 \\
\cline { 2 - 5 } & Chin-cap & 17 & 1,78 & 4,57 \\
\hline \multirow{2}{*}{ ay } & Edge-wise & 15 & 7,14 & 15,42 \\
\cline { 2 - 5 } & Chin-cap & 17 & 2,92 & 4,49 \\
\hline \multirow{2}{*}{ ay } & Edge-wise & 15 & 5,73 & 12,78 \\
\cline { 2 - 5 } & Chin-cap & 17 & 2,80 & 5,40 \\
\hline \multirow{3}{*}{ ay } & Edge-wise & 15 & 2,56 & 4,10 \\
\cline { 2 - 5 } & Chin-cap & 17 & 4,29 & 10,74 \\
\hline \multirow{2}{*}{6 ay } & Edge-wise & 15 & 4,42 & 8,12 \\
\cline { 2 - 5 } & Chin-cap & 17 & 1,70 & 4,90 \\
\cline { 2 - 5 } & Edge-wise & 15 & 2,14 & 4,98 \\
\cline { 2 - 5 } & Chin-cap & 17 & 1,79 & 2,42 \\
\hline
\end{tabular}

Tablo 3. Edge-wise ve chin-cap gruplarında ACTH'nin zamana bağlı değişikliklerini gösteren ortalama ve Standard sapma değerleri.

\begin{tabular}{|l|c|c|c|c|}
\hline \multicolumn{1}{|c|}{ Zaman } & Grup & $\mathrm{n}$ & Ortalama & Standart sapma \\
\hline \multirow{2}{*}{$\begin{array}{l}\text { Tedavi } \\
\text { öncesi }\end{array}$} & Edge-wise & 11 & 35,34 & 25,97 \\
\cline { 2 - 5 } 1 hafta & Chin-cap & 12 & 26,68 & 10,72 \\
\hline \multirow{2}{*}{2 hafta } & Edge-wise & 11 & 28,47 & 20,38 \\
\cline { 2 - 5 } & Chin-cap & 12 & 29,45 & 5,84 \\
\hline \multirow{2}{*}{ ay } & Edge-wise & 11 & 23,32 & 11,10 \\
\cline { 2 - 5 } & Chin-cap & 12 & 27,75 & 14,15 \\
\hline \multirow{2}{*}{2 ay } & Edge-wise & 11 & 27,94 & 20,00 \\
\cline { 2 - 5 } & Chin-cap & 12 & 31,62 & 14,72 \\
\hline \multirow{2}{*}{4 ay } & Edge-wise & 11 & 38,31 & 25,31 \\
\cline { 2 - 5 } & Chin-cap & 12 & 26,95 & 14,48 \\
\hline \multirow{2}{*}{6 ay } & Edge-wise & 11 & 38,09 & 20,39 \\
\cline { 2 - 5 } & Chin-cap & 12 & 31,10 & 14,38 \\
\hline & Edge-wise & 11 & 33,36 & 14,42 \\
\cline { 2 - 5 } & Chin-cap & 12 & 32,58 & 15,81 \\
\hline
\end{tabular}


Tablo 4. Edge-wise ve chin-cap gruplarında prolaktinin zamana bağlı değişikliklerini gösteren ortalama ve Standard sapma değerleri.

\begin{tabular}{|c|c|c|c|c|}
\hline Zaman & Grup & $\mathrm{n}$ & Ortalama & Standart sapma \\
\hline \multirow{2}{*}{$\begin{array}{c}\text { Tedavi } \\
\text { oncesi }\end{array}$} & Edge-wise & 16 & 6,63 & 3,99 \\
\cline { 2 - 5 } 1 hafta & Chin-cap & 17 & 7,72 & 3,63 \\
\hline \multirow{2}{*}{2 hafta } & Edge-wise & 16 & 6,71 & 4,89 \\
\cline { 2 - 5 } & Chin-cap & 17 & 7,94 & 3,77 \\
\hline \multirow{2}{*}{1 ay } & Edge-wise & 16 & 6,74 & 2,63 \\
\cline { 2 - 5 } & Chin-cap & 17 & 9,20 & 6,13 \\
\hline \multirow{2}{*}{2 ay } & Edge-wise & 16 & 6,68 & 5,77 \\
\cline { 2 - 5 } & Chin-cap & 17 & 8,12 & 4,27 \\
\hline \multirow{3}{*}{4 ay } & Edge-wise & 16 & 7,10 & 2,61 \\
\cline { 2 - 5 } & Chin-cap & 17 & 7,54 & 3,93 \\
\hline \multirow{2}{*}{6 ay } & Edge-wise & 16 & 6,62 & 3,09 \\
\cline { 2 - 5 } & Chin-cap & 17 & 7,15 & 3,95 \\
\hline & Edge-wise & 16 & 6,43 & 1,92 \\
\cline { 2 - 5 } & Chin-cap & 17 & 8,30 & 4,26 \\
\hline
\end{tabular}

Kortizol

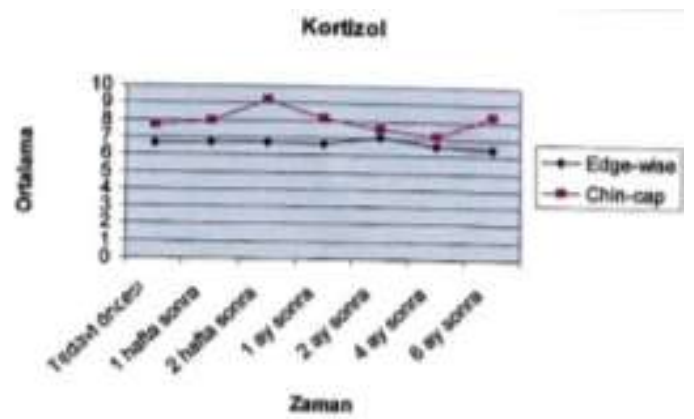

Şekil 1. Kortizolün zamana bağlı değişimini gösteren diyagram

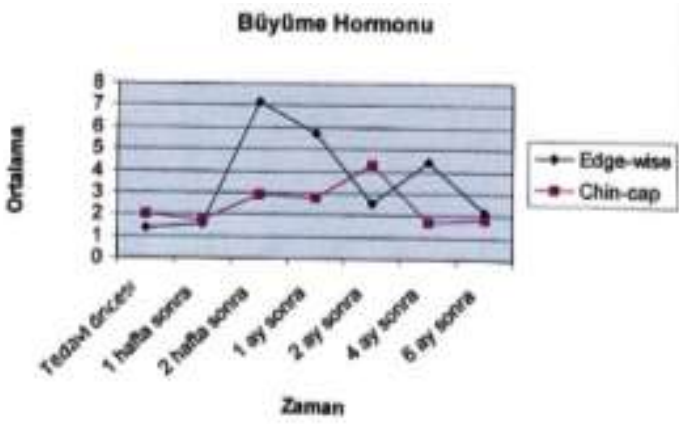

Şekil 2. Büyüme hormonunun zamana bağlı değişimini gösteren diyagram.

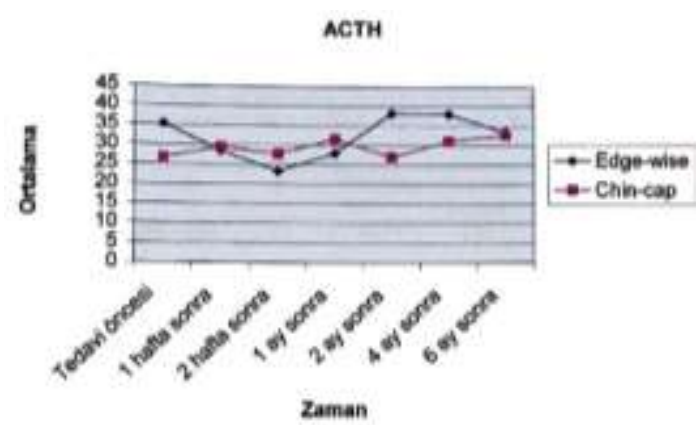

Şekil 3. ACTH'nin zamana bağlı değişimini gösteren diyagram.

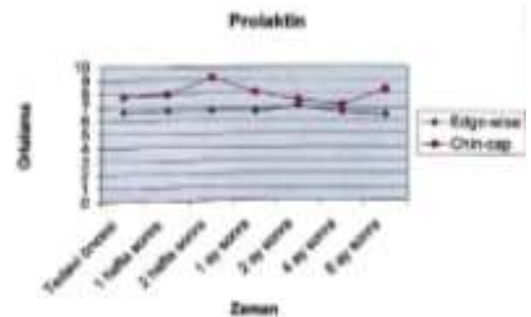

Şekil 4. Prolaktinin zamana bağlı değişimini gösteren diyagram.

Chin-cap uygulanan bireylerde ise, bu durumun tam tersi olarak, takip edilen süre sonunda başlangıç kortizol, ACTH ve prolaktin düzeylerinde istatistiksel olarak anlamlı olmayan bir artış görülürken, büyüme hormonunda ise yine istatistiksel olarak anlamlı olmayan seviyede azalma tespit edilmiştir. Edge-wise ve chin-cap grupları arasındaki psikolojik farklılıkları değerlendirmek amacıyla uygulanan Student's t testi sonuçları analiz edildiğinde psikolojik yönden gruplar arası önemli bir farklılığa rastlanılmamıştır.

Tedavi öncesi ile tedavinin farklı zaman periyotlarında, hastaların psikolojik durumunda meydana gelen değişiklikleri gösteren Eşleştirilmiş $t$ testi sonuçları Tablo 5'te verilmiştir. Bulunan sonuçlara göre; tedavi öncesindeki mevcut psikolojik durumun, tedavi süresi boyunca önemli olarak değişmediği görülmüştür. Başlangıç kaygı hâli, her bir zaman diliminde genel olarak azalmıştır. Fakat bu azalmanın istatistiksel olarak önemli olmadığı görülmüştür.

Tablo 5. Birleştirilmiş grupta başlangıç psikolojik değerlerinin zamana bağlı değişimini gösteren eşleştirilmiş $t$ testi sonuçları.

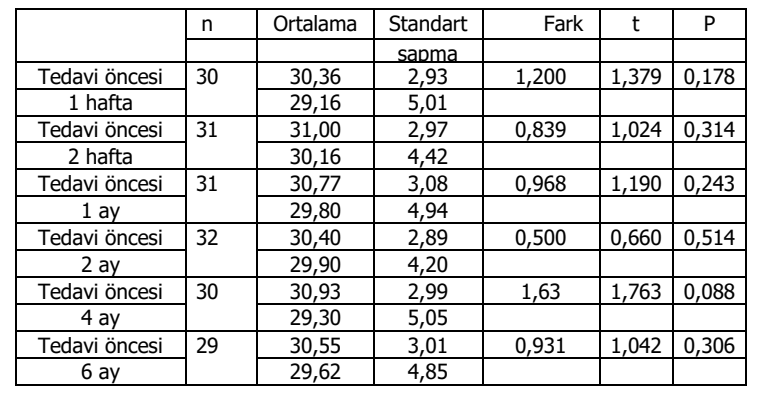

\section{TARTIŞMA}

Otonom sinir sistemini uyaran herhangi bir stimulus, stres olarak adlandırılır. ${ }^{7}$

Yüksek ve düşük ısı, atmosfer basıncındaki değişiklikler, radyasyon, ışık, mekanik faktörler, gürültü ve uzun süreli vibrasyon fiziksel stres olarak sayılabilir. ${ }^{18}$

Stresin organizmada ölçülebilir değişikliklere yol açtığı bilinmektedir. Nabız artışı, terleme, ${ }^{19,20}$ elektro- 
ensefalogram (EEG) ve elektrokardiyogramda (EKG) değişikliklerin yanı sıra, stres hormonlarının artışı da saptanabilmektedir. ${ }^{19}$

Fiziksel veya psikolojik travmanın stres ortamı yaratarak hipotalamusun uyarımasına, böylece stres hormonlarının salınımına neden olduğu gösterilmiştir. ${ }^{19}$

Dental tedaviyle ilişkili fiziksel ve emosyonel travma, öncelikle hipotalamo- hipofizer aktiviteyi etkiler. Travma özellikle kortikotropin salınımını başlatır. Böylece, ACTH'nın hipofiz ön lobundan kana salınımı artar ve kortizol üretmek için adrenal korteksi stimüle eder. ${ }^{21,22}$ Otonom sinir sistemi adrenal medullayı uyararak; katekolamin, adrenalin ve noradrenalin üretilir. Katekolaminlerin daha yüksek plazma konsantrasyonları kalp hızını ve kardiak volümü artııı. Vazokontriksiyona sebep olur. Bütün bunlar da sistolik ve diastolik kan basıncını artıır. ${ }^{22}$

Strese karşı oluşan fizyolojik cevaplar; kan, tükürük ${ }^{19,21-26}$ ve idrar ${ }^{22,25,26}$ analizleri gibi çeşitli parametreler aracılığı ile incelenebilir.

Kan örneğinin alınması invasiv, ağrılı ve pratik olmayan bir yöntemdir. ${ }^{19,21-26}$ Ancak stres hormonu da denilen serum kortizolü, stresi değerlendirme çalışmalarında iyi bir parametre olarak görülmektedir. 22,27

Tükürüğün incelenmesi; diş hekimliği, endokrinoloji, pediatri, immünoloji, klinik patoloji, fizyoloji gibi birçok bilim dallarında gittikçe ilgi çeken sahalardan biri olmaktadır. ${ }^{23}$

Tükürüğün kompleks yapısını; kandan tükürüğe geçen elektrolitler, vitaminler, ilaçlar, hormonlar ve su oluşturur. İlaç ve hormonların plazma ve tükürük seviyelerinin birbirleriyle orantılı olduğu da bilinmektedir. ${ }^{19,21,28,29}$

Kortizol tükürükten alınan örnekte de incelenebilir. Bu yöntemin hasta için daha kolay, stressiz ve noninvasiv olması gibi avantajları vardır. Ayrıca tükürük örneğinin alınması kompleks ve ağrılı prosedürler gerektirmez. ${ }^{19,21,23-26}$ Pek çok araştırmada, çeşitli psikolojik ve fizyolojik stresler kullanılarak, HypothalamoPituitary-Adrenocortical Axis (HPA) fonksiyonunun belirlenmesinde tükürük kortizolünün rolü gösterilmiştir. ${ }^{30}$

Bunun yanı sıra bazı dezavantajları da vardır. Kortizol tükürükte düşük konsantrasyonda bulunduğundan, biyokimyasal analizlerinin hassas yöntemlerle yapılması gerekir. Bazı dental işlemler sırasında tükürüğe kan bulaşabilir. Kontamine olmuş tükürük numunesinde kortizol değeri, hatalı olarak yüksek çıkabilir. ${ }^{24}$ Stres ve dinlenme sırasındaki değişiklikler, henüz sistemli olarak analiz edilememektedir. ${ }^{25}$

Stressiz ve noninvaziv olarak kolayca toplanabilen bir diğer yöntem, idrardır. Ancak idrardaki korti- zol konsantrasyonu, strese karşı uzun dönem cevabı yansıtır. Serum kortizolünün ani değişikliklerini göstermez. ${ }^{26}$

Bu sebeplerden dolayı, uyguladığımız tedavi yöntemlerinin stres hormonlarına olan etkilerini incelemek için kan örnekleri üzerinde çalışıldı. Stres hormonu olarak; serum kortizol, büyüme hormonu ve prolaktin seviyeleri ile plazma ACTH düzeyleri analiz edildi.

Dental hastalar emosyonel nedenler ve/veya ağrıya bağı olarak stresle karşı karşıya kalırlar ve bu streslere verdikleri fizyolojik cevaplar; kan basıncı ve kortizol konsantrasyonundaki önemli artışlar şeklindedir. ${ }^{22}$ Gerçekten de diş hekimliğindeki uygulamalar ile organizmada stres yaratan faktörler olan ağrı ve korku arasında yakın bir ilişki mevcuttur. ${ }^{19,31}$

Stres hormonlarını değerlendirebilmek için kan örneğinin alınması da çocuk hastalarda korkuyu provoke ederek stres kaynağı olabilir. ${ }^{19,21,26}$

Büyümekte olan prognatik bireylerin tedavisinde chin-cap çok eskiden beri kullanılan bir aygıttı ${ }^{31,32}$ Mandibular büyüme kaynağının kondil kıkırdağı olduğu, invivo ve invitro çalışmalarla gösterilmiştir. ${ }^{34,35}$ Kondilin mekanik streslere cevap verme özelliğinden yararlanılarak, mandibuler büyüme yönünün değiştirildiği ifade edilmiştir. ${ }^{36,37}$

Bu çalışmada uygun zaman, uygun şiddet ve yönde uygulanarak, dentofasial yapılar ve TME (Temporo Mandibular Eklem)'de değişiklik meydana getiren ortopedik kuvvet, fiziksel stres olarak adlandırıldı.

Ortodontik tedavi sırasında, diş hareketinin oluşabilmesi için uygulanan kuvvetle, alveol kemiğinde basınç ve gerilim sahaları meydana gelir. Basınç sahalarında kemik rezorbsiyonu, gerilim sahalarında ise kemik depozisyonu meydana gelmekte ve bu olaylar ortodontik diş hareketi olduğu müddetçe devam etmektedir. 38,39

Ayrıca dişe uygulanan kuvvetler, destek periodontal dokularda stres ve bu stresin sebep olduğu fiziksel değişikliklerle sonuçlanır. Bununla beraber mekanik stimuluslar, hücre metabolizmasını etkileyerek biyolojik hücresel cevap uyandırırlar. ${ }^{40}$

Çalışmamızda edge-wise mekanikleri aracılığı ile alveol kemiğinin basınç sahalarında rezorbsiyon, gerilim sahalarında depozisyon oluşturan ortodontik kuvvet, fiziksel stres olarak değerlendirildi.

Yapılan literatür incelemesinde; dental işlemlere bağlı vücudun fizyolojik ve endokrinolojik cevabını inceleyen çok az sayıda araştırmaya rastlanmıştı. Bu nedenle çalışmamızın amacı, pubertal büyüme atıııı başlamamış bireylerde, hem ağız içi hem de ağız dışı 
mekaniklerin, stres hormonlarının salınımına yol açıp açmayacağını incelemek ve ortodontik tedavi adı altında yaptığımız uygulamaların vücut için bir stres kaynağı olup olmadığını belirlemektir.

Ağız içi mekanikler olan ark telleri ile ortodontik kuvvet, dişlere devamlı olarak uygulandı. Devamlı kuvvetler; biyolojik etki derecesine göre, kapiller damar basıncının $\left(15-20 \mathrm{gr} / \mathrm{cm}^{2}\right)$ altında olan hafif kuvvetlerdir. ${ }^{41,42}$ Devamlı ortodontik kuvvetlerin şiddeti, başlangıçta yüksek olup zamanla azalmaktadır. ${ }^{43}$

Bu nedenle hastalar 3 haftada bir kontrol edilerek ya ark telinin değiştirilmesi ya da mevcut ark telinin aktive edilmesi ile optimal kuvvet yeniden sağlanmıştır.

Ortodontik tedaviyle dişlere, kuvvet uygulandıktan 3-5 gün sonra, basınç bölgelerinde rezorbsiyon ve 7-14 gün sonra gerilim bölgelerinde depozisyon olmaktadır. ${ }^{44,45}$ Yani alveol kemiğinde remodeling olayları meydana gelmektedir. Bu yüzden hastalardan, ortodontik tedaviye başlamadan önce ve diş hareketinin ilk işaretlerinin oluşmaya başladığı 1 . haftadan itibaren kan alınmaya başlanmıştır. Ayrıca tedavi öncesi ölçümler; 1. hafta, 2. hafta, 1., 2., 4. ve 6. ay ölçümleri için kontrol grubunu teşkil etmiştir.

1960'lı yıllardan günümüze kadar geçen süre içerisinde, strese karşı organizmanın cevabını inceleyen çalışmalarda; araştırıcılar materyal olarak deney hayvanlarını kullanmışlar, metot olarak da soğuk, immobilizasyon, eter, gürültü, vibrasyon gibi streslerin etkilerini incelemişlerdir.

Deneysel çalışma sonuçları, klinik uygulamalara büyük ölçüde ışık tutmaktadır. Ancak şu da unutulmamalıdır ki, deney hayvanları ile insanlar arasında gerek anatomik gerekse fonksiyon ve alışkanlıklar bakımından birçok fark bulunmaktadır. ${ }^{46} \mathrm{Bu}$ nedenle deneysel çalışma sonuçlarıyla, insanlardan elde edilecek sonuçların tamamen uymasını beklemek hatalı olabilir. Örneğin rat'larda, insan ve diğer memelilerin aksine strese maruz kalma, büyüme hormonunun hızlı bir düşüşü ile sonuçlanır.

Kokka ve arkadaşları, ${ }^{47}$ rat'larda plazma büyüme hormonu ve kortikosteron konsantrasyonları arasında ters bir ilişki olduğunu belirtmişlerdir. Çünkü ACTH sekresyonunun fizyolojik, psikolojik ve farmakolojik stimülasyonu, büyüme hormonu salınımının inhibisyonu ile sonuçlanır. Bu bulgular, stresin rat'larda büyüme hormonu sekresyonunu inhibe ettiği görüşünü doğrulamaktadır.

Dental işlemlere bağlı fizyolojik stres, sadece birkaç çalışmada incelenmiştir. ${ }^{24,30}$ Fakat oral uygulamaların, emosyonel strese etkisini inceleyen çok fazla sayıda çalışma mevcuttur ${ }^{19,21,25,27,48,49}$
Armario ve Jolin, ${ }^{8}$ erişkin Sprague-Dawley türü erkek rat'larda gürültü, plastik tüpte sınırlı kalma ve immobilizasyon gibi stres şekillerini kullanmışlar ve bu streslerin şiddeti ile uygulama sürelerinin; serumdaki ACTH, somatotropin ve tirotropin konsantrasyonlarına olan etkilerini incelemişlerdir.

Gibbs, $^{50} 1984$ yılında yaptığı bir çalışmada, erkek rat'lara hareketsizlik, soğuk ve eter streslerini uygulayarak periferal plazmada oksitosin, vazopressin ve ACTH hormonlarının seviyelerini ölçmüştür. ACTH seviyesinin hareketsizlik, soğuk ve eter stresine maruz kalan rat'larda kontrol grubuna göre, sırasıyla yaklaşık 8.5 ve 10 katı olarak arttığını bulmuştur.

Noel ve arkadaşları, ${ }^{51}$ cerrahi, egzersiz, gastroskopi gibi birçok stres durumunda, insan plazma prolaktinindeki önemli artışları incelemişlerdir. Başlangıç prolaktininin yaklaşık 5 katı olarak gözlenen en büyük artışın, genel anestezi altında cerrahi operasyon geçirmiş bireylerde olduğunu belirlemişlerdir.

Vongsavan ve arkadaşları ${ }^{52}$ yaptıkları bir çalışmada, cerrahi çekim gerektiren, gömük alt 3. molar dişlere sahip 11 hastaya, oral cerrahi uygulayarak plazma $\beta$-endorfin, ACTH ve kortizol seviyelerini bireylerin başlangıç endokrin kayıtları ile karşılaştırmışlardır. Cerrahi sırasında $\beta$-endorfin, ACTH ve kortizol seviyelerinin önemli derecede arttığı fakat operasyonun tamamlanmasından 30 dakika sonra tekrar başlangıç seviyelerine indikleri görülmüştür.

Vongsavan ve arkadaşları ${ }^{53}$ bir başka çalışmalarında, 3. molar dişin çekim stresine bağlı, prolaktin ve luteinizing hormon seviyelerindeki değişimi incelemişlerdir. Yapılan biyokimyasal analizlere göre, bu iki hormonun başlangıç değerlerinin operasyon esnasında önemli derecede arttığını bulmuşlardır.

Miller ve arkadaşları, ${ }^{24}$ muayene, profilaksi, restorasyon, kök kanal tedavisi ve çekim olmak üzere 5 tip rutin dental tedavi uygulanan, 50 erkek bireydeki fizyolojik stresi, tükürük kortizolü aracılığıyla ölçmüşlerdir. Tükürük örnekleri, dental işlemlerin başlamasından $10 \mathrm{dk}$. önce, hasta oturduktan $15 \mathrm{dk}$. sonra, dental işlemlerin sonunda ve işlemler tamamlandıktan 1 saat sonra alınmıştır.

Kortizol seviyesi; muayene, kanal tedavisi ve restoratif işlem yapılan hastalarda, işlemin başından sonuna kadar geçen sürede \% 15 oranında azalmıştır. Proflaksi yapılan hastalarda \% 55, diş çekimi yapılan hastalarda ise \% 148 oranında, kortizol seviyesinde artış belirlenmiştir. Sonuç olarak; diş çekimine karşı oluşan adrenal stres cevabı, diğer rutin dental işlemlerle ilgili cevaplardan daha büyük bulunmuştur.

Castejón-Casado ve arkadaşlarının ${ }^{54}$ yaş orta- 
lamaları 10 yıl olan 78 çocuğun cerrahi öncesi ve sonrası ACTH, kortizol ve $\beta$-endorfin konsantrasyonlarını değerlendirdikleri çalışma, postoperatif hormonal cevabın; incelenen hormon seviyelerinin cerrahiden 1 saat sonra artışı ile karakterize olduğunu göstermiştir. Bu çalışmada ACTH ve kortizol değerleri, cerrahiden 24 saat sonra normale dönerken, $\beta$ endorfin seviyesi artmış durumda kalmıştır.

İnsan ve hayvanlarda plazma kortikosteronun akut strese verdiği cevaplar, yaygın olarak incelenmesine rağmen, tekrarlayan ve kronik olarak uygulanan streslere verdiği cevaplar, daha az dikkat çekmiştir. ${ }^{55}$

Stres kaynağına akut olarak maruz kalmanın, aşırı sempato-adrenomedullar ve hipofizer-adrenokortikal aktivite sonucu, plazma kortikosteron konsantrasyonunu artırdığı tespit edilmiştir. ${ }^{56,57}$ Bunun aksine aynı stres uyaranının, kronik ve tekrar tekrar uygulanması ile nöroendokrin sistemlerin verdikleri cevaplarda azalma olabilmekte ve bu durum adaptasyon olarak adlandırılmaktadır. ${ }^{55,58}$

Rat'larda $^{46,59}$ emosyonel stresin etkisine ilişkin araştırmalar olmakla birlikte akut ve kronik gürültü stresinin anterior hipofiz hormonlarına etkilerini inceleyen çalışmada ${ }^{60}$ akut stresin kortikosteron, prolaktin, luteinizing hormon ve tirotropin sekresyonunu artırırken, büyüme hormonu sekresyonunu inhibe ettiğini tespit etmişlerdir. Aynı stresin kronik uygulanması durumunda, adı geçen hormonların verdiği cevapta azalma yani strese karşı adaptasyon meydana gelmiştir. $^{60}$

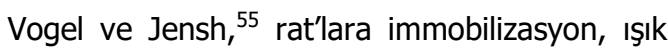
ve gürültü streslerini tekrar tekrar uygulayarak 3 haftalık stres periyodunun sonuna doğru, kortikosteronun plazma seviyesinin oldukça önemli derecede arttığını, 3 haftalık iyileşme periyodu ve uyarana yeniden maruz kalma ile kortikosteron seviyesinde, daha az bir artış olduğunu göstermişlerdir. Bu durum kortikosteronun kronik strese adaptasyon gösterdiğini açıklamaktadır.

Çalışmamızda da, 6 ay boyunca sürekli olarak uygulanan ortodontik kuvvete karşı stres hormonlarının adaptasyon göstererek, başlangıç seviyelerinin minimal düzeyde azalması, bazı araştırıcıların bulgularıyla uyumludur. ${ }^{55,59,61,62}$

Yapılan çalışmalarda, ${ }^{56,58,63,64}$ kronik ve tekrarlayan strese maruz kalışı takiben görülen adaptasyonun; stresin şiddeti, süresi ve stimuluslar arası aralığın değişkenliğine bağlı olduğu tespit edilmiştir.

Literatürde çalışmamıza benzer tek çalışma olan Takimoto ve arkadaşlarının ${ }^{65}$ çalışmasında, ortodontik tedavinin 17 ketosteroidlerin miktarında yaptığı deği- şiklikler incelenmiştir. Seçtikleri 40 adet wistar rat'larından 8 grup oluşturup, elde ettikleri bu deney gruplarına sırası ile 2, 4, 12, 24, 48, 72, 96, 168 saatlik ortodontik tedavi uygulamışlardır. Uygulamalar üst santral dişlere yapılmış ve her bir dişe 25 gr.'Iık kuvvet olmak üzere toplam $50 \mathrm{gr}$ kuvvet olacak şekilde ayarlanmıştır.

İşlem sonrası alınan kan örneklerinde yapılan laboratuvar incelemesinde; ortodontik tedavinin 4, 12 ve 24 saat uygulandığı gruplarda 17 ketosteroid düzeyindeki artışın 2 kat olduğu, 96 ve 168 saat kuvvet uygulanan gruplarda ise kontrol grubuna benzer oranlar elde edildiği görülmüştür.

Çalışmamızda da ortodontik tedaviden 1 hafta sonra, kortizol düzeyinde önemli bir değişiklik olmaması, Takimoto ve arkadaşlarının ${ }^{65} 168$ saat yani 7 gün boyunca kuvvet uyguladıkları grupta, kontrol grubuna benzer bulgular elde etmeleriyle paralellik göstermektedir.

Her iki çalışmanın kan alma dönemlerindeki farklılıktan dolayı, başka bir karşılaştırma yapmak mümkün olmamıştır. Bu çalışmada deney süresi toplam 7 gündür. Çalışmamızda ise stresin kronik dönem etkilerinin incelenmesi amaçlandığı için deney süresi 6 ay sürmüştür.

Ortopedik bir aygıt olan çeneliğin, stres hormonlarına olan etkilerini inceleyen herhangi bir literatüre rastlanmamıştır. Bu sebepten bulgularımız, literatür bulgularıyla karşılaştırılamamıştır.

Ortodonti literatüründe tedavileri farklı yöntemlerle gerçekleştirilmiş hastaların, psikolojik yapılarında meydana gelen değişimlerin konu edildiği çeşitli makaleler yayınlanmıştır. ${ }^{11,66,67}$

Spielberger $^{68}$ yapılacak psikoloji araştırmalarında, yaş taban sınırı olarak 14 yaş ve üzerinin kullanılması gerektiğini bildirmiştir. Çünkü araştırıcıya göre, davranış bilimlerinde kişinin psikolojik karakterinin oturmuş olarak kabul edildiği yaş sınırı 14'tür.

Ancak pubertal büyüme atılımı kızlarda 10 , erkeklerde 12 yaş civarında başlamaktadır. ${ }^{69}$ Araştırmamızı da pubertal büyüme atılımı başlamamış bireyler üzerinde yürüttüğümüz için durumluluk ve sürekli kaygı envanteri 9-13 yaşları arasındaki çocuklara uygulanmıştır.

Literatürde ortognatik cerrahi hastalarının korku, kaygı gibi temel psikolojik durumunu tanımlayan parametrelerin sorgulandığı, uzun dönem takip çalışmaları mevcuttur. ${ }^{66,70}$ Ancak konvansiyonel sabit tedavi gören hastaların, psikolojik karakterini belirlemeye yönelik yapılan araştırmaların az olduğu görülmüştür. ${ }^{11,65,71}$ 
Kiyak ve arkadaşları, ${ }^{67}$ konvansiyonel ortodontik tedavi gören hastalar üzerinde yapmış oldukları çalışmada, ortodontik tedavinin zamanla moral skorlarında önemli değişiklikler meydana getirdiğini ve stresli bir olay haline dönüştüğünü bildirmişlerdir. Ancak tedavinin tamamlanması ile tüm emosyonel değerlerin normal seviyeye döndüğü rapor edilmiştir.

Uysal ve arkadaşları, ${ }^{10}$ ortodontik tedavisine yeni başlanmış ve tedavisi 1 yıldır devam eden hastaların, temel psikolojik durumlarında meydana gelen değişimleri incelemişler ve tedavi başındaki hastaların durumluluk ve sürekli kaygılarının yüksek olduğunu ancak 1 yıldır tedavisi devam eden hastalarda bu değerlerin normale döndüğünü tespit etmişlerdir. Ortodonti hastalarında da tedavinin başında bilinmeyene karşı duyulan korkunun, kaygı seviyelerinin yükselmesine neden olduğu düşünülmektedir. Daha sonra yüksek kaygı seviyeleri gerek kurulan iletişim gerekse uygulanan işlemlerin öğrenilmesiyle normale dönmektedir.

Laskin, ${ }^{72}$ ortodontik tedaviler süresince hasta psikolojisinin değiştiğini ve etkili bir iletişimle hastanın psikolojik yapısının temelini oluşturan korku, kaygı, stres gibi faktörlerin azaltılabileceğini vurgulamıştır.

Vorela ve Garcia Camba, ${ }^{66}$ cerrahi hastalarında psikolojik parametrelerin kısa bir süre içinde, büyük oranda değişebildiğini ifade etmişlerdir. Çünkü ortognatik tedaviler sonunda yüz görünümünün hemen değiştiği, değişen yüz yapısıyla ilişkili olarak da psikolojik yapının kısa zamanda farklılaştı̆ı ifade edilmiştir. Aynı araştırmada, konvansiyonel ortodontide değişikliklerin daha yavaş oluştuğu ve bu yöntemle tedavi edilen vakaların, psikolojik parametrelerindeki farklılaşmanın daha uzun sürede meydana geldiği belirlenmiştir. Dolayısıyla ortodontik tedaviler sırasında daha uzun süreli psikolojik incelemelerin yapılması gerektiği vurgulanmışır.

Ağız, diş ve çene yapılarında bozukluk bulunan bireyler, görünüşleri ile ilgili konularda alay edilmeye ve eleştirilmeye karşı çok hassastırlar. Bu nedenle ortodontik tedavilerin hasta üzerindeki psikolojik baskısı ve ortodontik tedaviler sırasında hastaların içinde bulunduğu psikolojik durum, dikkat edilmesi gereken bir konudur.

Çalışmamız kapsamındaki hasta gruplarında da, tedaviye başlamadan önce ve takip edilen 6 ay boyunca psikolojik değerlendirme yapılmıştır. Sonuç olarak; başlangıçtaki mevcut emosyonel durumun, tedavinin seyriyle beraber değişmediği belirlenmiştir.

Elde ettiğimiz bu sonuca göre; çocuk hastanın sempatisini kazandığımız ya da en azından antipati oluşturmadığımız ve onun beklentilerini karşıladığımız düşüncesindeyiz. Hastalarımızın tedavi öncesinde bulunan endişe ve kaygılarının tedavi süresince daha da artmamasını; hastanın tedavisine başlanarak onun bu stresini ortadan kaldırmamıza ve hasta-hekim arasındaki ilişkilerin üst seviyede tutulmasına bağlamaktayız.

\section{SONUÇLAR}

Genel tıp dallarında olduğu gibi ortodontide de düzensizliklerin iyileştirilmesi sırasında organizmaya zarar vermemek veya muhtemel biyolojik zararları kontrol altına almak amaçlanmaktadır. Bu görüşlerin ışı̆ında çalışmamızda şu sonuçlar elde edilmiştir.

1. Hormonal faaliyetler; vücudun gerek büyüme ve gelişiminin normal olarak devam etmesi, gerekse fonksiyonların fizyolojik ve dengeli olması açısından önemlidir. Çalışmamızın da stres hormonlarında önemli bir değişikliğe yol açmaması, uyguladığımız tedavi tekniklerinin hormonal dengeyi bozmadığını göstermektedir.

2. Başarılı tedavilerin hasta üzerinde psikolojik ve fiziksel travma oluşturmadan tamamlanan tedaviler olduğu unutulmamalıdır.

3. Tek bir tane molar diş çekiminin dahi stres hormonlarını artırmasına rağmen, çalışmamızda dişsel ve iskeletsel seviyede yapılan düzeltmelerin böyle bir değişikliğe sebep olmaması; ortodontik ve ortopedik kuvvetlerin vücut için zararlı etkilerinin olmadığını göstermektedir.

4. Her iki gruptaki bireylerin psikolojik durumları değerlendirildiğinde, hastaların tedavi öncesi ve sonrasında verdikleri cevaplarda önemli farklar gözlenmemiştir. Bu nedenle, tedavinin başında umut ve heyecan dolu olan birçok bireyin, tedavi- nin ilerlemesiyle beraber uygulanan mekaniklerin çıkarımasını isteyen, sabırsız bireyler haline gelmesi; ortodontik tedavi süresinin uzun olması ve yeme-içme ile ilgili birtakım alışkanIıkların terk edilmesi ile ilişkilendirilebilir.

5. Bireylerin başlangıç psikolojik parametrelerinin tedavinin seyriyle beraber azalması, her ne kadar istatistiksel olarak anlamlı olmasa da bu çalışma, ortodontinin bireylerin güzellik ve estetiğine katkıda bulunduğunun bir kanıtı niteliğindedir.

6. Çalışmamız; ortodonti, biyokimya ve pediatri olmak üzere 3 farkı branşın ortaklaşa yürüttüğü, multidisipliner bir çalışmadır. Literatür incelemesinde, ortodontinin biyokimyasal etkilerine yönelik çalış- maların azlığı dikkat çekmektedir. Dolayısıyla bu konu ile ilgili elde ettiğimiz bulguları yorumlaya- bilecek, daha fazla çalışmanın yapılması gerektiğini düşünmekteyiz. 
NOT: Maddi destek ve çıar ilişkisi:

Calışmayı maddi olarak destekleyen kişi/kurulus yoktur ve yazarların çıkara dayalı bir ilişkisi yoktur.

\section{KAYNAKLAR}

1. Cannon WB, Bringer CAL, Fritz R. Experimental hyperthyroidism. American Journal of Physiology, 1914; 36: 363. "Alınmıştır" Mc Cance KL, Huether $\mathrm{SE}$, eds. Pathophysiology The biologic basis. for disease in adults and children. Second edition. St.Louis: Mosby-Year Book, Inc. 1990: 299-317.

2. Cannon WB. Stresses and strains of homeostasis. Am J Med Sci 1935; 189:1-14

3. Selye $\mathrm{H}$. The general adaptation syndrome and the diseases of adaptation. J Clin Endoc 1946; 6: 117-230.

4. Selye HP. Perspectives in stress research. Perspectives in Biology and Medicine, 1959; 2(4): 403-416. "Alınmıştır" Mc Cance KL, Huether SE, eds. Pathophysiology The biologic basis for disease in adults and children. Second edition. St.Louis: Mosby-Year Book, Inc. 1990: 299-317.

5. Mc Cance KL, Shelby J. Stress and disease. In: Mc Cance KL, Huether SE, eds. Pathophysiology The biologic basis for disease in adults and children. Second edition. St.Louis: Mosby-Year Book, Inc. 1990: 299-317.

6. Marti O, Armario A. Anterior pituitary response to stress: Time-related changes and adaptation. Int J Devl Neuroscience, 1998; 16: 241-60.

7. Ganong WF. Tıbbi Fizyoloji. 20. Baskı, İstanbul: Nobel Matbaacılık, 2002: 383-410.

8. Armario $A$, Jolin $T$. Influence of intensity and duration of exposure to various stressors on serum TSH and GH levels in adult male rats. Life Sci 1988; 44: 215-21.

9. Bieliauskas LA. Stress and its relationship to health and illness. Boulder, Co: Westview Press. 1982 "Alınmıştır" Mc Cance KL, Huether SE, eds. Pathophysiology The biologic basis for disease in adults and children. Second edition. St.Louis: Mosby-Year Book, Inc. 1990: 299-317.

10. Uysal T, Karaman Aİ, Sarı Z, Sargın N. Ortodontik tedavilerin hasta psikolojisine etkisi. Türk Ortodonti Derg 2003; 16: 1-8

11. Tung AW, Kiyak HA. Psychological influences on the timing of orthodontic treatment. Am J Orthod Dentofac Orthop, 1998; 113: 29-39.

12. Baydaş B, Erdem A, Yavuz İ. Sınıf III maloklüzyonlu bireylerde Wunderer aktivatörünün etkisinin incelenmesi. Türk Ortodonti Derneği
Uluslararası 8.Bilimsel Kongresinde sözlü bildiri olarak tebliğ edilmiştir. 27-30 Mayıs 2002, Antalya.

13. Wieslander $L$, Lagerström $L$. The effect of activator treatment on Class II malocclusions. Am J Orthod, 1979; 75: 20-6.

14. Onat T. Emerk K, Sözmen EY. İnsan Biyokimyası. Ankara: Palme Yayıncılık, 2002: 481-507.

15. Deniz E, Gazilerli Ü. Çocukların ve erişkin bireylerin sefalometrik ölçümlerinin karşılaştırılması. Türk Ortodonti Derg 1990; 3: 21-32.

16. Greulich WW, Pyle SI. Radiographic atlas of skeletal development of the hand and wrist (Second edition). California London: Oxford University Press 1959: 230-321.

17. Aydemir Ö, Köroğlu $E$, eds. Durumluluk-Sürekli Kaygı Envanteri (STAI). In: Öner N, Le Compte A. Psikiyatride kullanılan klinik ölçekler. Ankara: Hekimler Yayın Birliği, Medico Graphics Ajans ve Matbaacılık Hizmetleri 2000: 153-63.

18. Mc Cance KL. Altered cellular and tissue biology. In: Mc Cance KL, Huether SE, eds. Pathophysiology the biologic base in adults and children. Second edition. St.Louis: Mosby-Year Book, Inc. 1990: 68.

19. Pinçe $S$, Akyüz $S$, Hekim N. Koruyucu rezin restorasyonu uygulamasının değişik aşamalarında çocuk hastanın yaşadığı stresin tükürük kortizol seviyesi ile saptanması. Pedodonti Klinik / Araştırma 1996; 3: 29-33.

20. Gülhan A. Pedodonti, İstanbul: İstanbul Üniv Rektörlüğü Basımevi ve Film Merkezi 1994: 5-12.

21. Akyüz S, Pince $S$, Hekim N. Children's stress during a restorative dental treatment: assessment using salivary cortisol measurements. J Clin Pediatr Dent 1996; 20: 219-23.

22. Brand HS, Gortzak RA, Palmer-Bouva CCR, Abraham RE, Abraham-Inpjin L. Cardiovascular and neuroendocrine responses during acute stress induced by different types of dental treatment. Int Dent J 1995; 45: 45-8.

23. Rantonen PJF, Penttilä I, Meurman JH, Savolainen K, Närvänen S, Helenius T. Growth hormone and cortisol in serum and saliva. Acta Odontol Scand 2000; 58: 299-303.

24. Miller CS, Dembo JB, Falace DA, Kaplan AL. Salivary cortisol response to dental treatment of varying stress. Oral Surg Oral Med Oral Patholog 1995; 79: 436- 41.

25. Morse DR, Schacterle GR, Furst ML, Krishnokoli Bose, BS. Stress relaxation, and saliva: A pilot 
study involving endodontic patients. Oral Surg 1981; 52: 308- 13.

26. Brand HS. Anxiety and cortisol excretion correlate prior to dental treatment. Int Dent J 1999; 49: 330-6.

27. Kandemir S, Okşan T, Alpöz AR, Ergezer G, Kabalak T. Salivary cortisol levels in children during dental treatment. J Marmara University Dental Faculty 1997; 2: 639-642.

28. Mandel ID. Salivary diagnosis: More than a lick and a promise. JADA 1993; 124: 85-7.

29. FDI Working Group 10, Core. Saliva: Its role in health and disease. Int Dent J 1992; 42: 291304.

30. Walker R, Fernando SA, Barker GR, Walker RF. Salivary cortisol levels before and after dental treatment. J Dent Res 1992; 71: 741.

31. Milgrom P, Weinstein P. Dental fears in general practice: New guidelines for assessment and treatment. Int Dent J 1993; 43: 288-93.

32. Mitani $H$, Fukazawa $H$. Effects of chincap force on the timing and amount of mandibular growth associated with anterior reversed occlusion (Class III malocclusion) during puberty. Am J Orthod Dentofac Orthop 1986; 90 454-63.

33. Graber TM, Vanarsdall RL. Orthodontics current principles and techniques. St Louis: CV Mosby, 2000; 545.

34. Copray JCVM, Jansen HWB, Duterloo HS. Growth of the mandibular condylar cartilage of the rat in serum-free organ culture. Archs Oral Biol 1983; 28: 967-74.

35. Tuominen M, Kantomaa T, Pirttiniemi P, Poikela A. Growth and type-II collagen expression in the glenoid fossa of the temporomandibular joint during altered loading: a stuy in the rat. Eur J Orthod 1996; 18: 3-9.

36. Graber LW. Chin-cup therapy for mandibular prognathism. Am J Orthod 1977; 72: 23-41.

37. Mimura $H$, Deguchi T. Morphologic adaptation of temporomandibular joint after chin-cup therapy. Am J Orthod Dentofac Orthop 1996; 110: 541-6.

38. Roberts WE, Goodwin WC, Heiner SR. Cellular response to orthodontic force. Dent Clin North Am 1981; 25: 3-17.

39. Davidovitch Z, Nicolay OF, Ngan PW, Shanfeld JL. Neurotransmitters, cytokines, and the control of alveolar bone remodeling in orthodontics. Dent Clin North Am 1988;32:411-35

40. Yoshikawa DK. Biomechanical principles of tooth movement. Dent Clin North Am 1981; 25: 19-26.
41. Gülyurt M. Ortodontik Tedavi. Erzurum: Atatürk Ünive Diş Hek Fak Ortodonti AD Ders Notları 1985.

42. Erdem A. Hareketli aygıtlarla tedavi (Tek çeneyle ilgili). Erzurum: Atatürk Ünive Diş Hek Fak Ortodonti AD Ders Notu 1993: 4.

43. Ülgen M. Ortodontik Tedavi prensipleri. 4. Baskı, İstanbul: İstanbul Üniv Basımevi, 1993: 424-6.

44. Engström C, Granström G, Thilander B. Effect of orthodontic force on periodontal tissue metabolism: A histologic and biochemical study in normal and hypocalcemic young rats. Am J Orthod Dentofac Orthop 1988; 93: 486-94.

45. Storey E. The nature of tooth movement. Am J Orthod 1973; 63: 292-314.

46. Campos AC, Fogaca MV, Aguiar DC, Guimaraes FS. Animal models of anxiety disorders and stress. Braz J Psychiatry 2013; 35: S101-11.

47. Kokka N, Garcia JF. George R, Elliott HW. Growth hormone and ACTH secretion: Evidence for an inverse relationship in rats. Endocrinology 1972; 90: 735-43.

48. Sheskin RB, Klein H, Lowental U. Assessment of children's anxiety throughout dental treatment by their drawings. J Dent Child 1982; March-April: 99- 106.

49. Sullivan C, Schneider PE, Musselman RJ Dummett CO, Gardiner D. The effect of virtual reality during dental treatment on child anxiety and behavior. J Dent Child 2000; May-June: 193-196.

50. Gibbs DM. Dissociation of oxytocin, vasopressin and corticotropin secretion during different types of stress. Life Sci 1984; 35: 487-91.

51. Noel GL, Suh HK, Stone JG, Frantz AG. Human prolactin and growth hormone release during surgery and other conditions of stress. J Clin Endocrinol Metab 1972; 35: 840-51.

52. Vongsavan N, Pavasuthipaisit K, Rakprasitkul S, Kitiyanant Y. $\beta$-endorphin, ACTH, and cortisol secretion in man during standardized oral surgical stress and effect of diazepam. J Med Assoc Thai 1990; 73: 443-9.

53. Vongsavan N, Rakprasitikul S, Pavasuthipaisit K. Luteinizing hormone and prolactin secretion during stress from surgery of the third molar in man. J Med Assoc Thai 1988; 71: 119-23.

54. Castejón-Casado J Moreno-Prieto M, ValladaresMendias JC, Alaminos-Mingorance M, LöpezCandel E, Ramirez-Navarro A. Hormonal response to surgical stress in schoolchildren. Eur J Pediatr Surg 2001; 11: 44-7. 
55. Vogel WH, Jensh R. Chronic stress and plasma catecholamine and corticosterone levels in male rats. Neuroscience Letters 1988; 87: 183-8.

56. De Boer SF, Koopmans SJ Slangen JL, Gugten JV. Plasma catecholamine, corticosterone and glucose responses to repeated stress in rats: effect of interstressor interval length. Physiology \& Behavior 1990; 47: 1117-24.

57. De Boer SF, Slangen JL, Gugten JV. Adaptation of plasma catecholamine and corticosterone responses to short-term repeated noise stress in rats. Physiology \& Behavior 1988; 44: 273-80.

58. Natelson BH, Ottenweller JE, Cook JA, Pitman D, McCarty R, Tapp WN. Effect of stressor intensity on habituation of the adrenocortical stress response. Physiology \& Behavior 1988; 43: 41-6.

59. Vandevska-Radunovic V, Murison R. Emotional stress and orthodontic tooth movement: effects on apical root resorption, tooth movement, and dental tissue expression of interleukin-1 alpha and calcitonin gene-related peptide immunoreactive nerve fibres in rats. Eur J Orthod 2010; 32:329-35.

60. Antonio A, Lopez-Calderon A, Jolin T, Balasch J. Response of anterior pituitary hormones to chronic stress: The specificity of adaptation. Neuroscience\&Biobehavioral Reviews 1986; 10: 245

61. Hashiguchi $\mathrm{H}, \mathrm{Ye} \mathrm{SH}$, Morris $\mathrm{M}$, Alexander $\mathrm{N}$. Single and repeated environmental stress: Effect on plasma oxytocin, corticosterone, catecholamines, and behavior. Physiology \& Behavior 1997; 61: 731-6.

62. Muir JL, Pfister HP. Corticosterone and prolaction responses to predictable and unpredictable novelty stress in rats. Physiology \& Behavior 1986; 37: 285-8.

63. De Boer SF, Gugten JV, Slangen JL. Plasma catecholamine and corticosterone responses to predictable and unpredictable noise stress in rats. Physiology \& Behavior 1989; 45: 789-95.

64. Pitman DL, Ottenweller JE, Natelson BH. Plasma corticosterone levels during repeated presentation of two intensities of restraint stress: chronic stress and habituation. Physiology \& Behavior 1988; 43: 47-55.

65. Takimoto K, Kwata T, Nakagawa H, Fuji M, Onishi $\mathrm{K}$. Changes in 17- ketosteroids level in the blood during experimental tooth movement induced by an orthodontic procedure. Nippon Kyosei Shika Gakkai Zasshi 1966; 25: 67-9.
66. Varela M, Garcia-Camba JE. Impact of orthodontics on the psychologic profile of adult patients: A prospective study. Am J Orthod Dentofac Orthop, 1995; 108: 142-8.

67. Kiyak HA, West RA, Hohl T, McNeill RW. The psychological impact of orthognatic surgery: A 9month follow-up. Am J Orthod , 1982; 8: 404-12.

68. Spielberger G. Haber. Psikoloji Dergisi, 1978; 3: 45 "Alınmıştır" Uysal T, Karaman Aİ, Sarı Z, Sargın N. Ortodontik tedavilerin hasta psikolojisine etkisi. Türk Ortodonti Derg 2003; 16: 1-8

69. Gazilerli Ü. Radyografi Teknikleri Röntgenografik Sefalometri El-Bilek Grafileri. Erzurum: Atatürk Ünive Diş Hek Fak Ortodonti AD Ders Notları 1987: 64.

70. Flanary CM, Barnvell GM, VanSickels JE, Littlefield. $\mathrm{JH}$, Rugh AL. Impact of orthognathic surgery on normal and abnormal personality dimensions: A 2-year follow-up study of 61 patients. Am J Orthod Dentofac Orthop, 1990; 98: 313-22.

71. Al-Shammery D, Michelogiannakis D, Rossouw E, Romanos GE, Javed F. Influence of psychological stress exposure on orthodontic therapy: A comprehensive review. J Invest Clin Dent 2019; 10: e12388.

72. Laskin DM.The doctor-Patient Relationship: A Potential Communication Gap. J Oral Surg 1979; 37: 786.

\section{Yazışma Adresi}

Dr. Öğrt. Üyesi Nurhan BAYINDIR DURNA

Atatürk Üniversitesi,

Diş Hekimliği Fakültesi

Ortodonti Anabilim Dalı, Erzurum

TIf: 0.442.2360944

E-mail: nurhanbayindir@atauni.edu.tr 